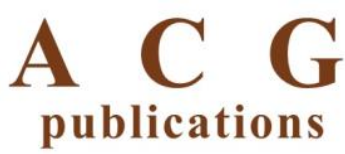

Rec. Nat. Prod. 15:5 (2021) 356-362

records of natural

products

\title{
Coumarins from Angelica dahurica and Their Antitumor Activities in Human MG-63 Osteosarcoma Cells
}

\author{
Weizhen Chen $\oplus^{1}$, Guokai Wang $\oplus^{2 *}$, Ke Mei $\oplus^{3}$ and Jianyong Zhu $\oplus^{4 *}$ \\ ${ }^{1}$ Department of Medicine, Huangshan Vocational and Technical College, Huangshan, Anhui, 245000, \\ P. R. China \\ ${ }^{2}$ School of Pharmacy, Anhui University of Chinese Medicine, Anhui Province Key Laboratory of \\ Research \& Development of Chinese Medicine, Hefei, Anhui, 230012, P. R. China \\ ${ }^{3}$ Dahua Hospital of Xuhui District, Shanghai, 200237, P. R. China \\ ${ }^{4}$ Seventh People's Hospital of Shanghai University of Traditional Chinese Medicine, Shanghai, \\ 200137, P. R. China
}

(Received January 08, 2021; Revised February 21, 2021; Accepted February 23, 2021)

\begin{abstract}
A new coumarin, angedahurin A (1), and seven known analogues (2-8), were isolated from the roots of Angelica dahurica. Their structures were identified by extensive NMR, IR, and HR-ESIMS spectroscopic analyses. The cytotoxicities of coumarins 1-8 against MG-63 human osteosarcoma cell lines were screened. Compound 1 showed significant cytotoxic effects against MG-63 with an $\mathrm{IC}_{50}$ value of $7.2 \mu \mathrm{M}$, for comparison, the positive control, 5-FU, had an $\mathrm{IC}_{50}$ value of $32.4 \mu \mathrm{M}$. Morphological features of apoptosis activities were evaluated in 1-induced MG-63 cells and the results confirmed MG-63 cell apoptosis in a dose-dependent manner.
\end{abstract}

Keywords: Angelica dahurica; coumarin; apoptosis, cytotoxicity. (C) 2021 ACG Publications. All rights reserved.

\section{Introduction}

Osteosarcoma (OS) is one of the most common primary malignant bone tumours and is most prevalent in teenagers and young adults [1]. According to the US National Cancer Institute Surveillance, Epidemiology, and End Results program, the frequency of OS has increased by $0.3 \%$ per year over the last decade [2]. Currently, the most common treatment of osteosarcoma is combined use of chemotherapy and surgery. Despite major improvements in chemotherapeutic regimens, the survival rate of patients with osteosarcoma still lags behind the overall survival rates of patients with cancer in that age group, mainly because of the intrinsic or acquired drug resistance. Discovering novel preventive agents is thought to be an available strategy, which is mainly focused on the discovery of precise molecular targets for OS chemoprevention [3].

Angelica dahurica is a plant that belongs to the Angelica genus and is distributed in Northern and Northeastern China. The roots of A. dahurica called Bai-Zhi in traditional Chinese medicine that classified as a sweat-inducing drug able to counter harmful external influences on the skin, such as

\footnotetext{
*Corresponding author: wanggk@ ahtcm.edu.cn (Guokai Wang); jyzhu@foxmail.com (Jianyong Zhu) 


\section{Coumarins from Angelica dahurica}

cold, heat, dampness and dryness [4]. A. dahurica mainly contains coumarins, volatile oils, polysaccharides, and trace elements as the bioactive components [5]. Many of these coumarins showed significant cytotoxic, anti-inflammatory, antioxidant, and tyrosinase inhibitory activities [6]. As part of our screening program to explore antineoplastic compounds from Chinese herbs [3], in this study, the petroleum ether (PE) extract of A. dahurica showed a cytotoxic inhibitory activity. Subsequent chemical investigation led to the isolation of eight coumarins, including a new coumarin, angedahurin A (1), and seven known analogues (2-8) (Figure 1). The cytotoxicities of coumarins 1-8 against MG-63 human osteosarcoma cell lines were screened. Compound $\mathbf{1}$ showed significant cytotoxicities against MG-63 cell lines with an $\mathrm{IC}_{50}$ value of $7.2 \mu \mathrm{M}$. The positive control 5-FU against the MG-63 with an $\mathrm{IC}_{50}$ value of $32.4 \mu \mathrm{M}$. Herein, details of the isolation, structural elucidation, and cytotoxic activities of these compounds are described.<smiles></smiles>

1<smiles>COc1cc(OC)c2ccc(=O)oc2c1</smiles>

5<smiles>O=c1ccc2ccc(O)cc2o1</smiles>

2<smiles>COc1cc2ccc(=O)oc2c(O)c1OC</smiles>

6<smiles>COc1cc2ccc(=O)oc2cc1O</smiles>

3<smiles>COc1cc2oc(=O)ccc2c(OC)c1OC</smiles>

7<smiles>COc1cc2ccc(=O)oc2cc1OC</smiles>

4<smiles>COc1cc2ccc(=O)oc2c(OC)c1OC</smiles>

8

Figure 1. Structures of compounds 1-8 isolated from Angelica dahurica

\section{Materials and Methods}

\subsection{General Experimental Procedures}

Optical rotations were measured on a Rudolph Autopol I automatic polarimeter. IR spectra were measured on a Bruker Tensor 37 infrared spectrophotometer. The NMR experiments were performed on a Bruker AM-400 spectrometer at $25^{\circ} \mathrm{C}$. The mass spectra were recorded on an Agilent Q-TOF micro mass spectrometer. A YMC-Pack column $(250 \times 20 \mathrm{~mm}, 5 \mu \mathrm{m}$, Kyoto, Japan $)$ was used to perform the HPLC separations. A YMC-pack ODS-A column $(250 \times 10 \mathrm{~mm}, 5 \mu \mathrm{m})$ were used for semi-preparative HPLC separation. Silica gel (200-300 mesh) was acquired from Qingdao Haiyang Chemical Co. (P. R. China), C18 reversed-phase silica gel (12 nm, S-50 $\mu \mathrm{m}$, YMC Co., Ltd.), and Sephadex LH-20 gel (Amersham Biosciences) were used for column chromatography (CC). Fractions were monitored by TLC with precoated glass plates $\mathrm{GF}_{254}$, and spots were detected by spraying with $10 \% \mathrm{H}_{2} \mathrm{SO}_{4}$ in $\mathrm{EtOH}$, followed by heating.

\subsection{Plant Material}

The roots of A. dahurica were purchased from Bozhou baisai Pharmaceutical Company (Bozhou, Anhui Province, China). Prof. Guokai Wang (School of Pharmacy, Anhui University of Chinese Medicine) identified the specimens; a voucher specimen (NO.20191012) has been deposited at department of medicine, Huangshan Vocational and Technical College. 


\subsection{Extraction and Isolation}

The air-dried powder of the roots of A. dahurica $(5 \mathrm{~kg})$ was extracted with $3 \mathrm{~L}$ of $95 \% \mathrm{EtOH}$ three times, following which the extract solution was filtered and concentrated in vacuo to yield the crude extract $(510 \mathrm{~g})$. The extract was suspended in water $(3 \mathrm{~L})$ and successively partitioned with petroleum ether $(\mathrm{PE}, 3 \times 2 \mathrm{~L})$ and EtOAc $(3 \times 2 \mathrm{~L})$, to afford petroleum ether $(40.5 \mathrm{~g})$ and EtOAc $(56.1 \mathrm{~g})$. The PE extract $(40.5 \mathrm{~g})$ was subjected to silica gel CC $(10 \times 160 \mathrm{~cm})$ eluted with petroleum ether-EtOAc (100:1, 80:1, 50:1, 30:1, 10:1, 5:1, 2:1,1:1, and 0:1, v/v) to afford 5 fractions E1-E5. E1 $(6.0 \mathrm{~g})$ was loaded onto Sephadex LH-20 column and eluted with $\mathrm{MeOH}$ led to E1a-E1f. E1b were subjected to preparative $\mathrm{HPLC}\left(\mathrm{MeOH} / \mathrm{H}_{2} \mathrm{O}, 4: 1\right)$ to yield $2\left(7.5 \mathrm{mg}, t_{\mathrm{R}} 16 \mathrm{~min}\right)$ and $3\left(5.7 \mathrm{mg}, t_{\mathrm{R}}\right.$ $18 \mathrm{~min})$. E1c was separated by HPLC ( $\left.\mathrm{MeOH} / \mathrm{H}_{2} \mathrm{O}, 8: 2,3 \mathrm{~mL} / \mathrm{min}\right)$ to afford $1\left(8.9 \mathrm{mg}, t_{\mathrm{R}} 13 \mathrm{~min}\right)$ and $4\left(9.1 \mathrm{mg}, t_{\mathrm{R}} 15 \mathrm{~min}\right)$. E1d was purified by a semi-preparative HPLC (Eclipse XDB-C 18 column, $\left.\mathrm{MeOH} / \mathrm{H}_{2} \mathrm{O}, 7: 3,3 \mathrm{~mL} / \mathrm{min}\right)$ to yield $6\left(8.3 \mathrm{mg}, t_{\mathrm{R}} 11.3 \mathrm{~min}\right), 7\left(3.5 \mathrm{mg}, t_{\mathrm{R}} 13.5 \mathrm{~min}\right)$, and $\mathbf{8}$ (4.7 mg, $\left.t_{\mathrm{R}} 16.1 \mathrm{~min}\right)$. E2 was chromatographed on Sephadex LH-20 column chromatography $(\mathrm{MeOH})$ to yield 3 subfractions E2a-E2c, E2a was purified by preparative $\mathrm{HPLC}\left(\mathrm{CH}_{3} \mathrm{CN} / \mathrm{H}_{2} \mathrm{O}, 3: 2,3 \mathrm{~mL} / \mathrm{min}\right)$ to provide $5\left(7.3 \mathrm{mg}, t_{\mathrm{R}} 12.5 \mathrm{~min}\right)$.

\subsection{Spectroscopic Data}

Angedahurin A (1): Colorless powder; $[\alpha]^{25}{ }_{\mathrm{D}}-12.2(c 0.2, \mathrm{MeOH}) ; \mathrm{UV}(\mathrm{MeOH}) \lambda_{\max }(\log \varepsilon) 322$ (3.52), 204 (3.90) nm; IR (KBr) $v_{\max }$ 2928, 1740, 1697, 1615, 1365, 1241, 1005, 907, 823, 785, $629 \mathrm{~cm}^{-1}$; ${ }^{1} \mathrm{H}$ and ${ }^{13} \mathrm{C}$ NMR data, see Table 1; HRESIMS $m / z 245.1183[\mathrm{M}+\mathrm{H}]^{+}$(calcd. for $\mathrm{C}_{15} \mathrm{H}_{17} \mathrm{O}_{3}$, 245.1172).

\subsection{Cell Culture}

MG-63 human osteosarcoma cell line was obtained from the Cell Bank of the Chinese Academy of Sciences. The cells were maintained in DMEM containing $10 \%$ fetal bovine serum (Gibco BRL Co., Grand Island, NY, USA) at $37{ }^{\circ} \mathrm{C}$ in a humidified incubator containing $5 \% \mathrm{CO}_{2}$.

\subsection{Cell Viability Assay}

The 3-(4,5-Dimethylthiazol-2-yl)-2,5-diphenyltetrazolium bromide (MTT) assay was used to evaluate MG-63 cell viability as previously described [3]. Briefly, human MG-63 osteosarcoma cells were plated in 96-well plates $\left(6 \times 10^{4}\right.$ cells/well $)$ for $24 \mathrm{~h}$ and then incubated with compound $\mathbf{1}$ in various concentrations with or without LPS $(1.0 \mu \mathrm{g} / \mathrm{mL})$ for an additional $24 \mathrm{~h}$. Then, the prepared MTT solution $(20 \mu \mathrm{L}, 5 \mathrm{mg} / \mathrm{mL})$ was added, and the cells were incubated for another $4 \mathrm{~h}$. After the formazan that formed was fully dissolved in DMSO and the absorbance was read at $560 \mathrm{~nm}$ on a microplate reader.

\subsection{Morphological Analysis}

In this experiment, $6 \times 10^{4}$ MG-63 cells were seeded in 12-well plates and treated with compound 1 for $24 \mathrm{~h}$. The cells were washed three times with phosphate-buffered saline (PBS). After the medium was replaced by nutrient-deprived medium (NDM) as a control or with various concentrations (1.8, 3.6, 7.2, 14.4, and $28.8 \mu \mathrm{M}$ ) of $\mathbf{1}$ added followed by incubation for an additional $24 \mathrm{~h}$. Subsequently, the cells were stained with $100 \mu \mathrm{L}$ of $200 \mu \mathrm{M}$ AO reagent, and incubated for 5 min in the dark. Then, the cell morphology was observed under a fluorescence microscope $(20 \times$ objective $)$.

\section{Results and Discussion}

\subsection{Structure Elucidation}

Compound 1 was isolated as a colorless powder with a molecular formula $\mathrm{C}_{15} \mathrm{H}_{16} \mathrm{O}_{3}$, as deduced by a HRESIMS ion at $\mathrm{m} / z 245.1183[\mathrm{M}+\mathrm{H}]^{+}$(calcd for $\mathrm{C}_{15} \mathrm{H}_{17} \mathrm{O}_{3}, 245.1172$ ), corresponding to eight 


\section{Coumarins from Angelica dahurica}

degrees of unsaturation. The IR spectrum exhibited absorption bands for carbonyl group $\left(1740 \mathrm{~cm}^{-1}\right)$, phenyl (1615 and $1505 \mathrm{~cm}^{-1}$ ), and terminal double bonds (1697 and $\left.1005 \mathrm{~cm}^{-1}\right)$. The ${ }^{1} \mathrm{H}$ NMR spectrum exhibited signals for three methyl groups $\left[\delta_{\mathrm{H}} 3.85(3 \mathrm{H}, \mathrm{s})\right.$ and $\left.1.47(3 \mathrm{H} \times 2, \mathrm{~s})\right]$, a set of olefinic protons of a terminal double bond $\left[\delta_{\mathrm{H}} 6.17(1 \mathrm{H}, \mathrm{dd}, J=17.1,11.0 \mathrm{~Hz}), 5.08(2 \mathrm{H}, \mathrm{dd}, J=17.1\right.$, $11.0 \mathrm{~Hz})]$, four olefinic protons $\left[\delta_{\mathrm{H}} 7.52(1 \mathrm{H}, \mathrm{s}), 7.34(1 \mathrm{H}, \mathrm{d}, J=2.4 \mathrm{~Hz}), 6.81(1 \mathrm{H}, \mathrm{dd}, J=8.5,2.4 \mathrm{~Hz})\right.$ and $6.78(1 \mathrm{H}, \mathrm{d}, J=8.5 \mathrm{~Hz})]$. The ${ }^{13} \mathrm{C}$ NMR spectrum, in combination with DEPT experiments, resolved 15 carbon resonances attributable to a carbonyl group $\left(\delta_{\mathrm{C}} 160.0\right)$, one terminal double bond ( $\delta_{\mathrm{C}} 145.5$ and 112.1), a phenyl bonds $\left(\delta_{\mathrm{C}} 162.0,155.0,128.5,112.9,112.2\right.$, and 100.0), one trisubstituted double bond ( $\delta_{\mathrm{C}} 137.7$ and 131.7 ), three methyls (including one methoxyl), and one $\mathrm{sp}^{3}$ quaternary carbon. As six of the eight degrees of unsaturation were accounted for by one carbonyl group, a phenyl group, and four double bonds, the remaining degrees of unsaturation required that $\mathbf{1}$ was dicyclic system. The stated information above, coupled with literature reports and biogenetic considerations [7], established the presence of a coumarin skeleton. Analysis of the ${ }^{13} \mathrm{C}$ NMR, HSQC and ${ }^{1} \mathrm{H}-{ }^{1} \mathrm{H}$ COSY spectra suggested a coumarin system with an additional $\mathrm{C}_{5}$ moiety, which consisted of a terminal double bond, a quaternary carbon and two tertiary methyl groups. In the HMBC experiment, correlations from $\mathrm{H}_{3} \mathrm{C}-4^{\prime} / 5^{\prime}\left(\delta_{\mathrm{H}} 1.47,3 \mathrm{H} \times 2\right)$ to $\mathrm{C}-3\left(\delta_{\mathrm{C}} 131.7\right)$ and $\mathrm{H}-2^{\prime}\left(\delta_{\mathrm{H}} 6.17,1 \mathrm{H}\right.$, dd, $J=17.1,11.0 \mathrm{~Hz})$ to $\mathrm{C}-3\left(\delta_{\mathrm{C}} 131.7\right)$, respectively, indicated that the $\mathrm{C}_{5}$ side-chain was located at $\mathrm{C}-3$. The ${ }^{1} \mathrm{H}$ and ${ }^{13} \mathrm{C}$ NMR data (Table 1$)$ showed high similarity to $3-\left(1 ', 1^{\prime}\right.$-dimethylallyl)-herniarin [8]. The differences between these two compounds were that the methoxy group at C-7 in 3-(1',1'dimethylallyl)-herniarin was moved to C-6 in 1 . This deduction was verified by the HMBC correlation from $\mathrm{H}_{3} \mathrm{CO}-\mathrm{C} 6\left(\delta_{\mathrm{H}} 3.85\right)$ to $\mathrm{C}-6\left(\delta_{\mathrm{C}} 162.0\right)$. The planar structure of 1 was further established by detailed interpretation of its 2D NMR data (Figure 2). Due to the structure of $\mathbf{1}$ does not involve chiral configurations, thus, new compound $\mathbf{1}$ was established as shown and named as angedahurin A.

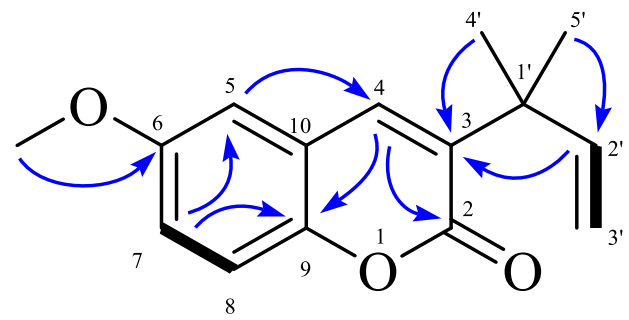

Figure 2. Selected ${ }^{1} \mathrm{H}-{ }^{1} \mathrm{H} \operatorname{COSY}(-)$ and $\operatorname{HMBC}(\rightarrow)$ correlations of $\mathbf{1}$

Seven known coumarins, umbelliferone (2) [9], scopoletin (3) [10, 11], 6,7-dimethoxycoumarin (4) [12], 5,7-dimethoxycoumarin (5) [13], fraxidin (6) [14], 5,6,7-trimethoxy-2H-benzopyran-2-one (7) [11], 6,7,8-trimethoxycoumarin (8) [15] were also isolated from the A. dahurica extract. Those known compounds were identified by spectroscopic data comparison with published literature.

Table 1. NMR Spectroscopic Data $\left({ }^{1} \mathrm{H} 400 \mathrm{MHz},{ }^{13} \mathrm{C} 100 \mathrm{MHz}, \mathrm{CDCl}_{3}\right)$ for $\mathbf{1}$

\begin{tabular}{cllcccc}
\hline No. & \multicolumn{1}{c}{$\boldsymbol{\delta}_{\mathbf{H}}$} & \multicolumn{1}{c}{$\boldsymbol{\delta}_{\mathbf{C}}$} & $\mathbf{N o}$ & & $\delta_{\mathbf{H}}$ & \multicolumn{1}{c}{$\boldsymbol{\delta}_{\mathbf{C}}$} \\
\hline 2 & & $160.0, \mathrm{C}$ & 9 & & & $155.0, \mathrm{C}$ \\
3 & & $131.7, \mathrm{C}$ & 10 & & & $112.9, \mathrm{C}$ \\
4 & $7.52, \mathrm{~s}$ & $137.7, \mathrm{CH}$ & $1^{\prime}$ & & & $40.3, \mathrm{C}$ \\
5 & $7.34, \mathrm{~d}(2.4)$ & $128.5, \mathrm{CH}$ & $2^{\prime}$ & $6.17, \mathrm{dd}(17.1,11.0)$ & $145.5, \mathrm{CH}$ \\
6 & & $162.0, \mathrm{C}$ & $3^{\prime}$ & $5.08, \quad 2 \mathrm{H}, \quad \mathrm{dd} \quad(17.1$, & $112.1, \mathrm{CH}_{2}$ \\
7 & & & & $11.0)$ & & $26.1, \mathrm{CH}_{3}$ \\
8 & $6.81, \mathrm{dd}(8.5,2.4)$ & $112.2, \mathrm{CH}$ & $4^{\prime}$ & $1.47, \mathrm{~s}$ & & $26.1, \mathrm{CH}_{3}$ \\
$6-\mathrm{OCH}_{3}$ & $3.85, \mathrm{~s}$ & $100.0, \mathrm{CH}$ & $5^{\prime}$ & $1.47, \mathrm{~s}$ & & \\
\hline
\end{tabular}




\subsection{Cytotoxic Effects of the Isolates}

The in vitro cytotoxicities of all the isolated compounds 1-8 against human MG-63 osteosarcoma cell lines were tested by the MTT assay. Compound $\mathbf{1}$ was found to be the most active compound, exhibiting an $\mathrm{IC}_{50}$ value of $7.2 \mu \mathrm{M}$ toward MG-63 cells, for comparison, the positive control 5-FU against the MG-63 with an $\mathrm{IC}_{50}$ value of $32.4 \mu \mathrm{M}$ (Figure 3).

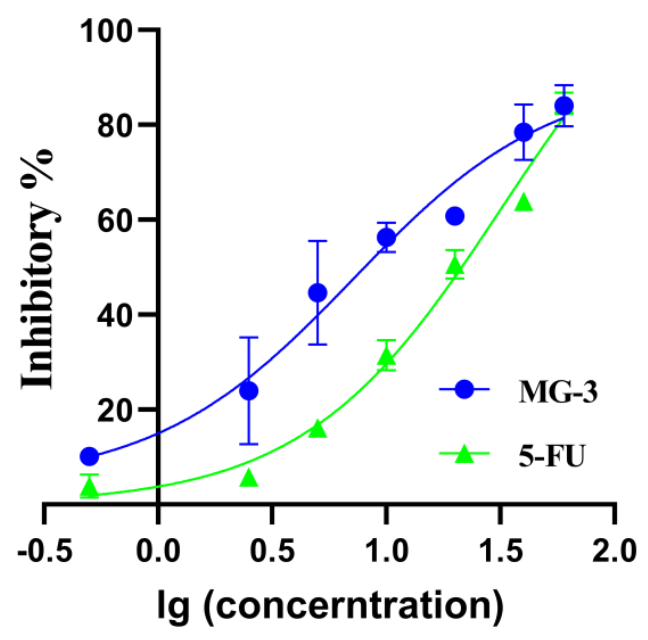

Figure 3. Inhibitory curves of compound 1 in human MG-63 osteosarcoma cells

\subsection{Morphological Changes in MG-63 Cells Treated with angedahurin A (1)}

To confirm the apoptosis-inducing effects of angedahurin A (1), a nuclear morphological evaluation of MG-63 cells was performed by fluorescence microscopy following staining acridine orange (AO) after treatment for $24 \mathrm{~h}$ with 1.8, 3.6, 7.2, 14.4, and $28.8 \mu \mathrm{M}$ concentrations of $\mathbf{1}$. Afterwards, the characteristic morphological features of apoptosis were examined under fluorescence microscope. Compared with the control group, treatment with $\mathbf{1}$ caused significant morphological changes, including the appearance of membrane blebbing and granular apoptotic bodies (Figure 4), with blue arrows highlighting apoptotic cells.
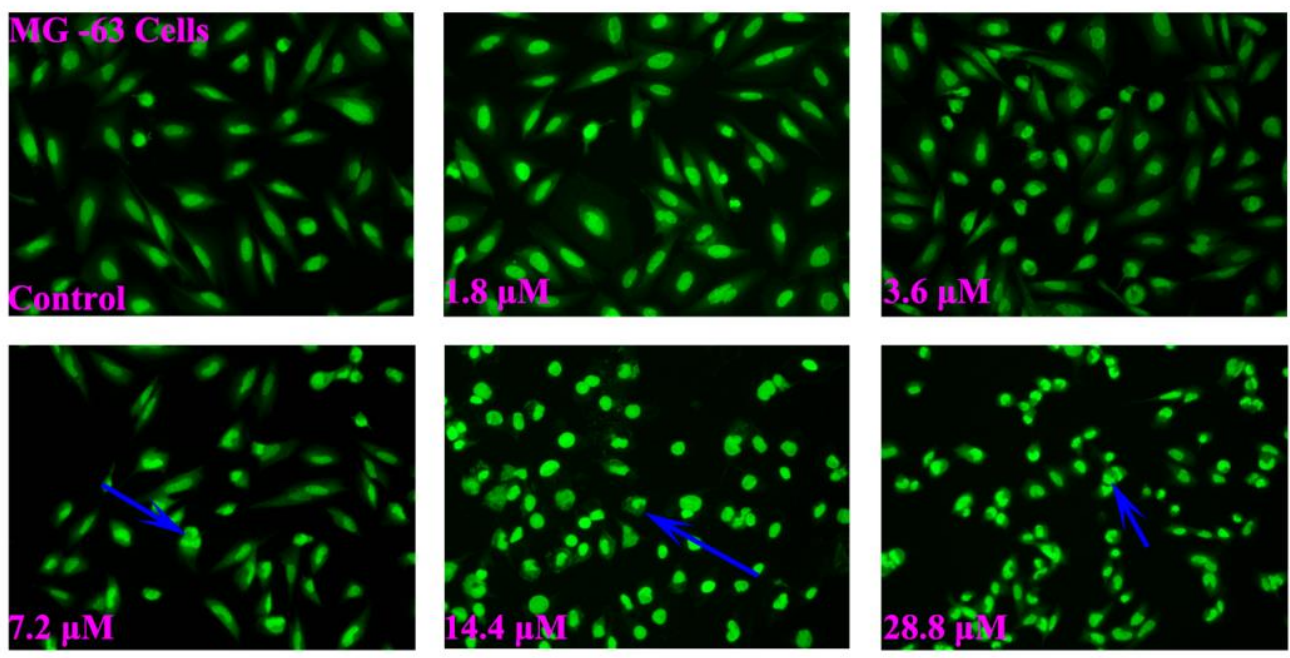

\section{Conclusions}

Figure 4. Evaluation of the effects of compound 1 on apoptosis

In this study, chemical investigation of petroleum ether extracts led to the isolation of eight coumarins including a new coumarin, angedahurin A (1), and seven known analogues (2-8). Their 


\section{Coumarins from Angelica dahurica}

structures were identified by extensive 1D and 2D NMR, IR, and HR-ESIMS spectroscopic analyses. The cytotoxicities of all the coumarins (1-8) were evaluated against MG-63 human osteosarcoma cell line. We considered any compound exhibiting an inhibition rate of less than $50 \%$ at $50 \mu \mathrm{M}$ to be inactive. The results showed that compound 1 exhibited significant cytotoxic effects against MG-63 with an $\mathrm{IC}_{50}$ value of $7.2 \mu \mathrm{M}$, for comparison, the positive control, 5-FU against the MG-63 with an $\mathrm{IC}_{50}$ value of $32.4 \mu \mathrm{M}$. The $\mathrm{IC}_{50}$ values of other compounds were all more than $50 \mu \mathrm{M}$. Morphological features of apoptosis activities were evaluated in 1-induced MG-63 cells and the results confirmed apoptosis in a dose-dependent manner.

\section{Acknowledgments}

We are grateful for financial support from the Quality engineering project of Huangshan Vocational and Technical College: Pharmaceutical Chemistry wisdom class Project (No. 2019zhkc01), Natural Science Foundation of Anhui province (No. 2008085MH289), National \& Local Joint Engineering Research Center of High-throughput Drug Screening Technology (No. G20181001), and Anhui Province College Excellent Young Talents Fund (No. gxyqZD2019035).

\section{Supporting Information}

Supporting information accompanies this paper on http://www.acgpubs.org/journal/records-ofnatural-products

\section{ORCID}

Weizhen Chen: 0000-0002-6483-7956

Guokai Wang: 0000-0002-3924-6169

Ke Mei: 0000-0002-1667-5833

Jianyong Zhu: $\underline{0000-0001-5922-9326}$

\section{References}

[1] Z. J. Yang, Q. P. Guo, Y. Cai, X. S. Zhu, C. H. Zhu, Y. L. Li and B. Li (2020). Poly(ethylene glycol)sheddable reduction-sensitive polyurethane micelles for triggered intracellular drug delivery for osteosarcoma treatment, J. Orthop. Translat. 21, 57-65.

[2] Y. Shi, R. H. He, Z. Zhuang, J. H. Ren, Z. Wang, Y. G. Liu, J. J. Wu, S. H. Jiang and K. Wang (2020). A risk signature-based on metastasis-associated genes to predict survival of patients with osteosarcoma, $J$. Cell. Biochem. 121, 3479-3490.

[3] H.T. Yuan, Q.F. Li, T. Tian, C.Y. Zhang, Z.Q. Huang, C.X. Fan, K. Mei, J. Zhou, X.-X. Zhai, S.B. Li and J.Y. Zhu (2020). Lathyrane diterpenoids from Jatropha podagrica and their antitumor activities in human osteosarcoma cells, Nat. Prod. Res. 1, 1-7. Doi: 10.1080/14786419.2020.1779719.

[4] R. Zhang, B. H. Xu and T. Y. Cao (2020). Characterization of the complete chloroplast genome of Angelica dahurica (Apiaceae) as an herb in China, Mitochond. DNA Part B-Resources 5, 678-679.

[5] L. Yang, Q. Li, Y. M. Feng and D. Y. Qiu (2020). Simultaneous determination of three coumarins in Angelica dahurica by ${ }^{1} \mathrm{H}-\mathrm{qNMR}$ method: A fast and validated method for crude drug quality control, $J$. Anal. Methods Chem. 14, 1-7. Article ID 8987560.

[6] P. H. Shu, J. P. Li, Y. Y. Fei, H. Q. Zhu, M. Z. Yu, A. Q. Liu, H. Y. Niu, S. M. Zou, X. L. Wei, Z. Y. Ju and Z. H. Xu (2020). Isolation, structure elucidation, tyrosinase inhibitory, and antioxidant evaluation of the constituents from Angelica dahurica roots, J. Nat. Med. 74, 456-462.

[7] Y. Matsuo, E. Yamaguchi, R. Hakamata, K. Ootomo, K. Takatori, H. Fukaya and Y. Mimaki (2020). Benzofuran and coumarin derivatives from the root of Angelica dahurica and their PPAR-gamma ligandbinding activity, Phytochemistry 173, 112301.

[8] V. K. Ahluwalia, R. P. Singh and S. Bala (1982). A versatile route for the synthesis of 3-(1',1'dimethylallyl)coumarins, Tetrahedron Lett. 23, 2049-2050. 
[9] N. Ingert, I. Bombarda, G. Herbette, R. Faure and C. Moretti, P. Raharivelomanana (2013). Oleodaphnoic acid and coriaceol, two new natural products from the stem bark of Wikstroemia coriacea, Molecules 18, 2988-2996.

[10] H. Tsukamoto, S. Hisada and S. Nishibe (1985). Coumarin and secoiridoid glucosides from bark of Olea africana and Olea capensis, Chem. Pharm. Bull. 33, 396-399.

[11] O. Kayser and H. Kolodziej (1995). Highly oxygenated coumarins from Pelargonium sidoides, Phytochemistry 39, 1181-1185.

[12] Z. Yan, J. Liu, D. Lu, R. Narlawar, P. Groundwater and P. Li (2014). Two new ceramides from the fruit pulp of Acanthopanax senticosus (Rupr. et Maxim) Harms, Nat. Prod. Res. 28, 144-149.

[13] N. E. Sandoval-Montemayor, A. García, E. Elizondo-Treviño, E. Garza-González, L. Alvarez and M. Del Rayo Camacho-Corona (2012). Chemical composition of hexane extract of Citrus aurantifolia and antiMycobacterium tuberculosis activity of some of its constituents, Molecules 17, 11173-11184.

[14] M. I. Yusupov and G. P. Sidyakin (1975). Fraxidin and isofraxidin from Artemisia scotina, Chem. Nat. Compund. 11, 94-94.

[15] Q. W. Shi, X. H. Su and H. Kiyota (2008). Chemical and pharmacological research of the plants in Genus Euphorbia, Chem. Rev. 108, 4295-4327.

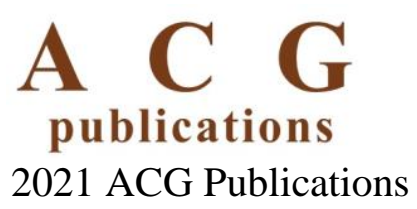

